\title{
What Holds us Together? Analyzing Biotech Field Formation
}

\author{
Jackeline Amantino de Andrade'
}

\begin{abstract}
This article proposes to analyze the formation of biotechnological field bringing actor-network theory's lens as contribution. Based on conclusions of studies developed by Walter Powell and colleagues it was held a research to analyze the diversity of institutional relations that are active by hemophilia therapies, the principle of generalized symmetry adopted for actornetwork theory is highlight to identify how socio-technical associations are assembled. Besides the interorganizational relations, research's findings indicate the scientific and technological contents have a significant mediating role to create and sustain those connections of knowledge. So, it is emphasized the need of a boarder theoretical discussion to enlarge explanations about the dynamics of organizational fields as well as innovation processes.
\end{abstract}

Keywords: Biotechnology; organizational field; actor-network theory; interorganizational relations; institutional theory; innovation.

\footnotetext{
' Department of Administration, Propad, Federal University of Pernambuco, Avenida dos Economistas, s/n, Cidade Universitária, Recife, PE, 50670-901, Brazil.Tel: +55 (8I) 2126-7I64. E-mail: jackeline.amantino@gmail.com
} 


\section{Introduction}

The aim of this paper is to analyze the formation of biotechnological field. The concept of organizational field is the start point to discussion, so this introduction situates the emergence of biotechnology and the theoretical questions around organizational theory. The following section deals with to situate central issues from our study, indicating methodological bases for data collection and their analysis. And, in the last two sections, the first presents data analysis while the second is discussed actor-network theory contributions to improve the understanding of socio-technical associations that configure the field.

According to Marques and Gonçalves Neto (2007), biotechnology is one of the oldest areas of knowledge and goes back many centuries ago to the manufacture of bread, beer and wine. In last century, modern biotechnology is emerging from scientific and technological relations in areas such as molecular biology, biochemistry, microbiology and genetics (Trigueiro, 2002), characterized by a "set of enabling technologies that allow to use, change and improve living organism or their parts, cells, organelles and molecules, to produce products, processes and services with economic applications in human and animal health, agriculture and environment." (Judice and Baêta, 2005: I7I).

In twenty-first century, biotechnology brings promise for the future of various technologies in many sectors and supply chains, being considered as an activity of high innovation, involving a lot of scientific and technological organizations beyond those directly linked to production, and characterizing an industry based on science. Its brand has a pronounced division of labor between universities, research organizations, biotech firms, large corporations, etc. that forming a dense network of relations and intensive use of knowledge based on technological capabilities. (Orsenigo, 2006; Powell, Koput and Smith-Doerr, 1996; Powell, 1999; Powell et al. 2002).

A biotechnology revolution had its landmark in 1973 when Stanley Cohen, from Stanford University, and Hebert Boyer, from University of San Francisco, developed the technique of recombinant DNA. This is the basis for genetic engineering and the rapid creation of knowledge-based firms (biotech firms) during the following years whose function was transfer scientific findings to the industry, at first. (Coriat, Orsi and Weinstein, 2003; Owen-Smith et al. 2002). Also in US, the Bayh-Dole Act (1980), as well as expansions of venture capital and other facilities for technological transfer have contributed to boom of biotech field which was primarily organized by access to new knowledge at local spillovers or international alliances, having the patents as one important information source to signal new process and products. (Niosi, 2003; Owen-Smith et al. 2002; Owen-Smith and Powell, 2004). Niosi (2003) identified this broad scope of interorganizational relations or network as a field that bears a new institutional framework to support biotechnological development, specifically referring to the Canadian case. Before, however, in another study about US, Powell (1999) inferred that those networks (in which partnerships, strategic alliances, and licensing agreements take place), highlight the emergence of a field characterized by heterogeneity of organizational forms. In seventies, such forms were particularly directed to scientific laboratories and universities, while in the eighties and nineties were extend to large pharmaceutical corporations and biotech firms, configuring geographical propinquity clusters at San Francisco Area Bay, Boston and San Diego, as well as within European regions. (Owen-Smith et al. 2002; Owen-Smith and Powell, 2004; Porter, Whittington and Powell, 2005; Powell, Packalen and Whittington, 20I0).

If, on the one hand, Niosi (2003) considers biotech field without any reference to the definition of DiMaggio and Powell (1991), on the other, Powell (1999) explicitly deals with the concept. An organizational field is "those organizations that, in aggregate, constitute a recognized area of institutional life: key suppliers, resources and product consumers, regulatory agencies, and other organizations that produce similar services or products." (DiMaggio and Powell, 1991: 64), so that the rationalization of organizations stems from the rationalization of organizational environments (Meyer, 2008), or, as Scott (1994) points out, field is a community of organizations that participate in the same meaning system, define by similar symbolic processes, and subject to common regulatory processes. And the structure of an organizational field is identified by increase in the extent of interaction among organizations in the field; the emergence of sharply defined interorganizational structures of domination and patterns of coalition; an increase in the information load with which organizations in a field must contend; and the 
development of mutual awareness among participants in a set of organizations that they are involved in a common enterprise. (DiMaggio and Powell, 1991: 65).

As Scott (1995) also suggests a field is institutionalized when a same institutional logical extend and directs the activities from an increase in the structural equivalence of all organizations by homogenization of routines and practices.

Powell et al. (2005: II45) note that in the late nineties, "the biotech field gained the coherence, and the pattern of reliance on collaboration proliferated, institutions emerged to both facilitate and monitor the process", implicitly indicating the normalization of routines and practices which, however, are recalcitrant to homogenization. Thus, "the diversity of institutional forms - public, private, and non-profit - that are active in the field is located in different selection environments." (Powell et al., 2005: I190).

Powell and Colyvas (2008: 287) point out that although commercial technological transfer in biotech field became institutionalized, also "the variation in responses reflects a profound tension between public and private science". So an institutional logic market-oriented prominent within biotech clusters since nineties (Porter, Whittington and Powell, 2005; Owen-Smith and Powell, 2004) could coexist with an open science logic widespread by public and non-profit research organizations, such as research institutes and universities, or by networks of researchers on the basis of collaborative research inherent to sciences and their invisible colleges. (Whittington, Owen-Smith and Powell, 2009).

As Owen-Smith and Powell (2008: 600) highlight the fields "are shaped by networks, which condition the formation of relationships and help establish their consequences" and disparate meanings could to represent a multiply of social embeddedness that is "the joint outcome of both networks and institutions". Whittington, Owen-Smith and Powell (2009) justify the intensive flux of knowledge, that characterizing biotech field, is also influences by multiple types of affiliation and the "pipelines" given the geographical propinquity. Explicitly the biotech field involves the circularity of social, economic, scientific and technological issues. And, because of this, the analysis of relations between networks and institutions needs to adopt "lens that emphasizes comparative dynamics." (Owen-Smith and Powell, 2008: 617).
In order to improve the dynamic analyses of organizational fields, we propose the lens of actor-network theory (ANT). Originally a "reflection about science", ANT puts on question "the general problem of social order" through a "dogged scrutiny of traditional dichotomies" such as "nature-society, subject-object and macro-micro". (Domènech and Tirado, 1998: 13). And, according Holt (2008: 23), "ANT gains much of its notoriety through advocating a socio-philosophical approach in which human and non-human, social and technical factors are brought together in the same analytical view."

The basis of ANT is the generalized principle of symmetry that was adopted by researches from social studies of science as Bruno Latour, Michel Callon and John Law. This principle allows not adopt artificial divisions so that the explanation is given by the mediation of elements before separate at poles from nature or from society. (Callon, 1989; Latour, 1994; 2000; Latour and Woolgar, 1997). In this sense, ANT is concerned to analysis the association of heterogeneous materials (Law and Hetherington, 2000), human and non-human, and especially how they are associated to produce socio-technical collectives. (Latour, 2004; 2005). "The concept of the 'actor-network was introduced to describe such associations" (Callon, Law and Rip, 1986: 105), therefore ANT enables to study assembling and stabilizations of those associations, highlights the mechanism through which social and natural world gradually will be shape, mapping out the accumulation of heterogeneous materialities that become more durable and spread out at time and space (Callon, 1986; Latour, 2000; 200I; 2005; Law, 1999).

\section{Methodological Issues}

The motivation of this study was based on the results of a research about the network of information on hemotherapy, developed by Fernandes (2010). Fernandes' study aimed to describe the socio-technical associations, using scientometrics and social network analysis as methodological resources to analyze a sample of 137 from a universe of 909 patents collected in the United States Patentand Trademark Office (USPTO) that were registered between the seventies and early twenty-first century.

First, this research was based on the graph resulting from Fernandes' study to identify the composition of relational structure between patents in twenty-first century. It was identified seven core patents. Then, we consulted 
annexes data from Fernandes' document to identify all who were assignees of those patents, identifying many organizations indicated in researches of Walter R. Powell and his colleagues as those that constitute regional biotech clusters in US.

This led us to question whether the clusters of hemophilia had similar characteristics to those identified by Powell. Also to question whether was possible to analyze the structuring of biotechnological field and to compare with Powell's conclusions.

This research has an exploratory and descriptive nature, however. Therefore, differs to researches developed by Powell and his colleagues that had an explanatory character, using a broad database collected from Bioscan, over the period 1988-2004 (see Owen-Smith and Powell, 2004 and Powell, Packalen and Whittington, 2010). Our date cover the period from 198I to 2005 of documentpatents that were collected from database of United States Patent and Trademark Office (USPTO).
We analyzed the seven core document-patent contents, and it was ruled out one of them, because was registered a similar method by same inventors, Harvey and Bette Pollard. Thus, in this study were considered six core patents, beyond those directly quoted by them, totalizing 52 documents. Also, we considered $4 \mathrm{l}$ documents, quoted by one of those cited patent, because its contents highlighted enrollments in three of six core patents.

So that, an amounted of 93 documents were analyzed, and $3 \mathrm{I}$ of them have not appeared in Fernandes' sample. On each document were collected the following data: the technology registered; inventors' names; assignee organizations; city and country of each organization; filing data; register date; government interest (when there), besides their abstracts and scientific contents.

For data analysis each of the six core patents, and those quoted by them, were regarded as a cluster. The Table I below presents a synthesis of each cluster, identifying the organizations that registered the patent and its host city, also state the name of the principal inventor of research team, and registered year.

\begin{tabular}{|c|l|l|l|l|}
\hline Cluster n. & \multicolumn{1}{|c|}{ Assignees Organization } & Principal Inventor & \multicolumn{1}{|c|}{ Cities } & \multicolumn{1}{|c|}{$\begin{array}{c}\text { Registered } \\
\text { Year }\end{array}$} \\
\hline 1 & Do not exist & Harvey Pollard & - & 2002 \\
\hline 2 & Cell Genesys Inc. & Richard Snyder & $\begin{array}{l}\text { South San Francisco, } \\
\text { CA }\end{array}$ & 2004 \\
\hline 3 & Chiron Corp. & Douglas Jolly & Emeryville, CA & 2004 \\
\hline 4 & $\begin{array}{l}\text { Virginia Tech Intellectual Prop. } \\
\text { and Department of Health from } \\
\text { USA government }\end{array}$ & $\begin{array}{l}\text { Oral Alpan } \\
\text { Washburg, VA and }\end{array}$ & 2007 \\
\hline 5 & Center for Blood Research DC & Denise Wagner & Boston, MA M and & 2008 \\
\hline 6 & $\begin{array}{l}\text { American Red Cross and Virginia } \\
\text { Tech Intellectual Prop. }\end{array}$ & William Velander & $\begin{array}{l}\text { Rockville, MD and } \\
\text { Blacksburg, VA }\end{array}$ & \\
\hline
\end{tabular}

Table I - Main Clusters of Hemophilia

We first examined the set of organizations and inventors of each cluster, also its location, in order to identify whether it was possible to establish some relations with Powell's findings, related institutional logic and geographical propinquity, the two main elements that characterize the field of biotechnology seconded by him. However, relations between organizations and between inventors were not clearly identified. Evidently it was taken into account that the average of 15 patents in each cluster cannot be comparable to 462 organizations that constituted the sample of those studies, but when we consider the technologies registered could be identified some relations.

Since it was not possible to do an analysis considering only social actors, this research adopted the principle of generalized symmetry from actor-network theory (Callon, 1986; Latour, 1994; 2000; 200I; 2004) taking into account both human (organizations and inventors) and non-human 
(technologies) actors to analyze associations within clusters. With this lens was possible concentrate attention on circulation of actors, following those that "modify a state of affairs by making difference" (Latour, 2005) and look to their "way of performing" (Law, 1999) into each cluster.

It was necessary to consider the content of each document-patent by adopting the concept of "inscription" as an organizing principle of the scientific facts, as Latour and Woolgar (1997), and analyzing the networks of problematisation as proposed by Callon, Law and Rip (1986) to trace the dynamic of science and technology, recognizing that "a patent application is a compromise between different strategies of enrollment." (Rip, 1986: 92). Therefore, it was necessary to understand a little more about gene therapy for the hemophilias consulting other documents, one in special published by World Federation of Hemophilia whose authors are David Lilicrap and Arthur R. Thompson.

Lilicrap and Thompson (2008: I) begin by explaining that "for a patient with hemophilia, gene therapy would allow continuous synthesis of a normal protein to correct the deficiency state in vivo." First, however, we must clarify the types of this hereditary genetic disease that cripples the body to control bleeding (hemorrhagic diathesis).

Hemophilia $A$ is the most frequently and refers to a sexlinked recessive deficiency of coagulation factor VIII and accounts for $85-90 \%$ of cases reported internationally, according to World Health Organization (WHO). Hemophilia B is caused by mutation in the factor IX gene, also known as Christmas disease. While Von Willebrand disease is hereditary and caused by a fall or a dysfunction of the protein called von Willerbrand factor affecting around $2 \%$ of world population.

Traditionally, the treatment for hemophilia involves plasma transfusions to replace the deficient clotting factor that are found in various blood products to ensure the homeostasis. Thus, there is a concern for the safety of plasma, as well as the quality of its fractionation. (see WFH, 2008). Also, the patients with hemophilia could develop inhibitors that fight proteins contained in those products requiring specific treatments.

Hemophilia has not cure, but adding a functional gene to a cell could be comparable as a cure. Lillicrap and Thompson (2008) distinguish therapy that uses modify somatic cells of a host from other experimental approaches that lead to transgenic animal as well as those directed to gene transfer and gene repair. According to them "the transfer of DNA into cells for gene therapy is accomplished by transduction, a controlled process that is mediated by vector or vehicles that attach to a cell surface and facilitate entry into the cell." (Lillicrap and Thompson, 2008: 2). The vectors for transduction commonly derive from viral nucleic acid backbone and the preclinical studies to gene therapy are concentrated in three types of them: retroviral vector; adenoviral vector and adeno-associated viral (AAV) vector. Also researchers are directed to non-viral vectors, alternative type cells and gene repair. Nowadays vector systems are capable to deliver factor IX or VIII cDNAs to host cells and express clotting factors in vivo efficiently as well as these factors can be expressed and secreted through the milk of a transgenic mammal, so therapeutic trials in human patients are being tested. Thus, hemophilia represents "a leading candidate condition for the successful application of gene therapy", and despite challenges of the development of safe, "effective methods to provide a "cure" for hemophilia remain feasible." (Lillicrap and Thompson, 2008: 9).

\section{Clusters Analysis}

In this section are described each cluster. Also an analytical synthesis is presented considering assignees organizations, types of therapies, geographic location and organizational forms.

The Cluster I is characterized by the enrollments of an artificial gland, a bioartificial pancreas, an extracorporeal reactor, a dried and sterilized gamma-globulin-fixed column, as well as implant techniques and therapies, and an apparatus for therapeutically treating immunological disorders and disease states. Those techniques was developed by universities of Massachusetts, Toledo and Brown, pharmaceutical multinational company, Merck, and other companies such as Industrikontakt from Scandinavian countries, and Asahi Kasei, a chemical company from Japan. All of them serve to Harvey and Bette Pollard develop methods for treating hemophilia A and $B$ and AIDS, and register a patent that does not have any assignee, but represents US government's interest. However, in this cluster is not possible to identify any mediation that assembles the patents with work of others inventors and institutions. So that the Pollards were limited to the laboratory boundaries, and do not 
mobilized a network as vehicle of translation to extend and trace new paths and entities, as suggests by ANT. At same time, this method is not specifically directed to protein or gene therapies, before is related to a treatment with a permeable membrane.

Cluster 2 refers to recombinant adeno-associated viral (AAV) vector for gene therapy of hemophilia A developed by Cell Genesys who belongs to aggregate of the biotech firms located at San Francisco Bay Area. The set of patents involve the Universities of Florida and Pennsylvania, the Children's Hospital of Philadelphia, the biotech firm Avigen, also located at San Francisco Bay Area (with two patents), and one no assignee patent that have a team of five inventors from North Carolina, Maryland and Tennessee. Thus, recombinant AAV vectors are combined to administering genes in animal muscle, to isolate DNA encoding Factor IX, for introduce foreign DNA in mammalian cells and constructing a hybrid gene vector, and to express vectors in mammalian genes as well as human cells, delivering nucleic acid which result in the production biologically active Factor VIII in vivo, what enabling Cell Genesys provides methods and materials for expressing a polypeptide with factor VIII activity comprising administering an rAAV vector through its recombinant, standing out a partnership between biotech firms that does not enroll other organizations from San Francisco Bay Area, however. Geographical propinquity is not exactly what characterizes this cluster, which assembles firms, and universities, inventors, the children's hospital to produce translations about $A A V$ vectors, and stabilize a gene therapy to hemophilia $A$.

Another biotech firm from San Francisco Bay Area, Chiron registers methods for administration of recombinant gene delivery vehicles for treatment of hemophilia and other disorders, composing Cluster 3. Three patents are cited without any assignee, two of them belonging to inventors of San Diego and another involving a team of British inventors with one from Maryland. The other technologies belong to Universities of Michigan and California, the Fred Hutchison Cancer Research Center from Seattle, and the Alexion, a global biopharmaceutical company founded in 1992, from Connecticut. Once again it has an enrollment of techniques laid out by a set of private, public and non-profit organizations. They assemble methods to delivery of proteins by catheterization and preserving an infectious recombinant virus; DNA constructs for retrovirus packaging cell lines; generation, concentration and efficient transfer of VSV-G pseudotyped retroviral; genetic alteration to introduction of nucleic acid expression particles to construct directing the expression of retroviral inhibitor activity of chimeric proteins into cells; retroviral vectors produced by producer cell lines as in vivo gene delivery vehicles and recombinant retroviruses expressing a protein that converts a pro-drug into a cytotoxic agent translating gene therapy based on retroviral vectors that overcome American boundaries.

In Cluster 4 are assembled techniques registered by American National Red Cross, Virginia Polytechnic Institute \& State University, American Red Cross, Virginia Tech Intellectual Properties, the Japanese pharmaceutical company, Dainippon, the biotech firm Biogen, the Shire Laboratorie (belonging Boston region), the biotech firm Avigen (San Francisco region), and the British PPL Therapeutic, to stabilize a oral treatment of hemophilia registered by the Secretary of the Department of Health and Human Service of US government and Virginia Tech Intellectual Properties. The Japanese company contributes with a pharmaceutical composition for oral administration containing coagulation factor VIII or IX which is assembled in translations to production of recombinant proteins in mammals' milk, as well as five transgenic mammals to expression of human protein $C$ in mammary tissue that incorporate DNA, also to expression human coagulation of factor VIII, to produce factor IX and DNA sequences with modified splice sites, to active factor IX in mammary tissue and of milk, and to expression of human coagulation factor VIII and von Willerbrand factor beside an AAV vector for expression of factor VIII by target cells and an oral induction of tolerance to parenterally administered non-autologous polypeptides. We have here an example of experimental approaches that lead to transgenic animal that are aimed to "generating female animals such as pigs that secrete human factors VIII or IX in their milk", as assigned by Lillicrap and Thompson (2008: 2), that also highlight one significant partnership between the American National Red Cross and Virginia Tech Intellectual Properties of Virginia Tech University to produce these socio-technical associations.

Cluster 5 involves two pharmaceutical compositions containing the P-selectin ligand protein and methods of treating inflammatory disease states characterized by P-selectin- and E-selectin-mediated intercellular adhesion registered by biotech firm Genetics Institute, 
from Cambridge (belonging Boston region), that are translated with two other techniques developed by same firm, specifically a nucleic acid encoding a novel P-selectin ligand protein and a method of inhibiting P-selectin ligand activity. Also two patents of biotech firm Cytel, from San Diego (belonging San Diego region), related to antibodies to P-selectin and a method for detecting the presence of P-selectin, and another registered by biotech firm Protein Design, from Mountain View (San Francisco region), related to cross-reacting monoclonal antibodies specific for $\mathrm{E}$ - and $\mathrm{P}$-selectin and others techniques registered by Universities of Oklahoma and California, as well as New England Medical Center Hospital from Boston concern to a modulation of inflammatory responses by administration of GMP-140 or antibody to GMP-140; a plasma and polymer containing surgical homeostatic adhesives; an inhibition of L-selectin and P-selectin mediated binding using heparin and a method of inhibiting PADGEMmediated or ELAM-I mediated leukocyte adhesion using; and an inhibitor comprising a Le.sup.x core component, including too a method for fabricating a high voltage MOS device developed by United Microelectronics corporation from Taiwan, are all enrolled in this cluster, that do not properly represent a biotechnology. Here also do not identify any significant geographical propinquity laid out by Powell and colleagues, so that the network center is located in the translations of P-selectin for the Centre for Blood Research, from Boston, to develop methods of treating hemophilia or Von Willebrand disease with P-selectin, indicating their concern over the development of protein inhibitor to treatments with plasma.

Finally, in Cluster 6 methods of producing a substance comprising a peptide, involves incorporating a DNA sequence coding for the peptide into a gene of a mammal (such as a sheep) coding for a milk developed by British biotech firms, Pharmaceutical Proteins and PPL Therapeutics, are assembled with recombinants techniques to express in mammary tissues of transgenic mammals a heterologous polypeptide and human protein $C$ both registered by American Red Cross with partnership of the US government - Department of Health and Human Services and Virginia Intellectual Property Division respectively, as well as the production of recombinant proteins in mammals' milk registered by Biogen, the technique to improve factor IX product developed by non-profit organization Blood Systems, from Arizona, and the factor IX cDNA inserted into an expression vector that has the British government agency, National
Research Development, as assignee. All those translations result in a recombinant Factor IX characterized by a high percentage of active protein obtained in the milk of transgenic animals that incorporate chimeric DNA molecules to treat hemophilia registered by American Red Cross and Virginia Tech Intellectual Properties. With the exception of Blood Systems, all cluster patents quote Biogen patent, one of the oldest biotech firms, founded in 1978 by biologists as Walter Gilter, Nobel price, and other researches from Harvard and Massachusetts Institute of Technology that belonging Boston region. However, the true actors that have a mediation to produce these sociotechnical associations are the transgenic mammal and the recombinant product in its milk, registered by Biogen.

From the above analysis of each cluster, we consider that the cluster I presented particular characteristics when is regarded the method registered, and does not be adequate to comparative analysis that will be discussed in the next section. Therefore, it was excluded of synthesis presents below. 


\begin{tabular}{|c|c|c|c|c|}
\hline Cluster & $\begin{array}{c}\text { Assignee } \\
\text { Organization }\end{array}$ & Hemophilia Therapy & $\begin{array}{l}\text { Geographic } \\
\text { Ties }\end{array}$ & Organizational forms \\
\hline 2 & Cell Genesys Inc. & $\begin{array}{l}\text { AAV vectors to factor } \\
\text { expression in host } \tilde{Q} \\
\text { cells }\end{array}$ & $\overline{\mathrm{US}}$ & $\begin{array}{l}\text { Biotech firms, universities, } \\
\text { hospital, and team of inventors }\end{array}$ \\
\hline 3 & Chiron Corp. & $\begin{array}{l}\text { Retroviral vectors } \\
\text { factor expression } \\
\text { host } \text { in cells }\end{array}$ & US-Britain & $\begin{array}{l}\text { Biotech firm, global } \\
\text { biopharmaceutical company, } \\
\text { universities, research center and } \\
\text { team of inventors }\end{array}$ \\
\hline 4 & $\begin{array}{lr}\text { Virginia } & \text { Tech } \\
\text { Intellectual Prop. and } \\
\text { Department of Health } \\
\text { from } \\
\text { government }\end{array}$ & $\begin{array}{l}\text { Transgenic animals } \\
\text { secrete human factor in } \\
\text { their milk }\end{array}$ & $\begin{array}{l}\text { US-Britain- } \\
\text { Japan }\end{array}$ & $\begin{array}{l}\text { Universities, government agency } \\
\text { non-profit organization, biotech } \\
\text { firms, large multinational } \\
\text { company and laboratory }\end{array}$ \\
\hline 5 & $\begin{array}{l}\text { Center for Blood } \\
\text { Research }\end{array}$ & $\begin{array}{l}\text { Plasma treatment with } \\
\text { P-selectin }\end{array}$ & US & $\begin{array}{l}\text { Research center, biotech firms, } \\
\text { universities and hospital }\end{array}$ \\
\hline$\overline{6}$ & $\begin{array}{l}\text { American Red Cross } \\
\text { and Virginia Tech } \\
\text { Intellectual Prop. }\end{array}$ & $\begin{array}{l}\text { Transgenic animals } \\
\text { secrete human factor in } \\
\text { their milk }\end{array}$ & US-Britain & 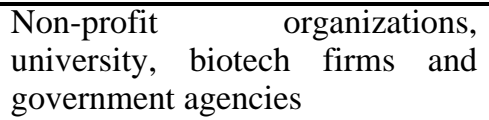 \\
\hline
\end{tabular}

Table 2 - Synthesis of cluster analysis

\section{Discussion and Conclusions}

Based on these results must now discuss at the first whether could be identified a formation of biotechnological field, or more properly an organizational field of hemophilia. When we consider the characteristics defined by DiMaggio and Powell (1991) for identifying this structure can be seen that there was an increase in information load over the years. For example, between the eighties and nineties has had an increase of $400 \%$ in the number of registered patents at our sample. Also can be identified a common enterprise to the development of hemophilia treatments referring to gene therapy or those related to improvements in the treatments with plasma that increased the extent of interaction, basically founded on technical and scientific contents, do not limited to organizations, but including too inventors and mainly techniques. However, we cannot identify "the emergence of sharply defined interorganizational structures of domination and patterns of coalition" (DiMaggio and Powell, 1991: 64).

As we highlight the interactions were not limited to interorganizational relations, the translations made possible the stabilization of relations that did not refers specifically to a coalition or domination, but the sharing of contents. Such interactions are related to human and non-human associations to "tell particular stories about particular relations”, as suggests Law (2008: 143).
This leading us to question and discuss what characterizes such interactions within the field. First, despite many organizations belong regional clusters as Powell and colleaguesidentified (see Powell, Packalen and Whittington, 2010; Whittington, Owen-Smith and Powell, 2009; Porter, Whittington and Powell, 2005; Owen-Smith and Powell, 2004), a geographical propinquity typically linking the organizations of Boston region, or San Francisco Bay Area region, or San Diego region, cannot be characterized, because, there were partnerships between organizations from several regions of US.

Considering the geographical propinquity it was only possible to identify the extent of interactions within the borders of US or beyond. Thus, we cannot consider the geographical propinquity as an explanation, only that the scientific contents are stretched across local and regional borders, and enroll it through the national and international boundaries. Therefore innovations in the treatment with $\mathrm{p}$-selectin and gene transfer using AAV vectors are restrict to US borders, while the gene transfer by retroviral vectors or transgenic mammals occur through partnerships especially between American and British organizations. 
At the same time, if there is a same institutional logic does not concern a structural equivalence of organizations or a same symbolic meanings system, as suggested by Scott (1994, 1995). Such logic must be considered in relation to scientific contents. This involves questions related to routines and practices, because both facts and values should be symmetrically considered, especially when we see collective formations, as proposes Latour (2004; 2005). So that, the collective "don't mean an action carried over by homogeneous social forces, but, on contrary, an action that collects different types of force woven together because they are different." (Latour, 2005: 74).

In each cluster it was identified the diversity of institutional forms - private, public, and non-profit - as Powell et al. (2005) point out. A constant presence of universities and biotech firms was mixed to research centers, hospitals, multinational companies, non-profit organizations, laboratories, team of inventors, and government agencies differently. They are not active in the field in different selection environments, however, as Powell et al. (2005) propose. They are active in the field because a non-human actor as one transgenic mammal enrolls them to mobilize their resources, for example. So, transgenic mammals, $\mathrm{p}$-selectin proteins, and $\mathrm{AAV}$ or retroviral vectors are those that act as actor-networks, constituting in the obligatory centers of passage to assemble different organizational forms, producing associations and transformations.

With this lens private and public tensions, suggested by Powell and Colyvas (2008), are not so evident, because an open science or a market-oriented logical is the effect not the cause of translations that produce the networks. As a consequence we could to say that there is no specifically "multiply of social embeddedness", as Owen-Smith and Powell (2008) point out, but a multiply of translations that joint networks and institutions. So that the translations shape relationships that are temporally stabilize, and result in therapies for hemophilia.

Thus, it was possible to follow the circularity of social, economic, scientific and technological issues in the biotechnological field. It was possible to accompany actors' translations through their fluid socio-technical associations where non-human actors performing as mediators. They were essential to assembling human actors, and to understanding how contents are enrolled by successive transformations, making knowledge circulate. So that, the core question in studies of field formation is not only to concern with "how a collection of organizations cohere into a community, engaged in common activities and subject to similar reputational and regulatory processes", as propose Powell, Packalen and Whittington (2010). However, we agree with these authors that a crucial role to create and sustain those interorganizational relations is pervaded for connections mediated through "anchor tenants", mainly when we see beyond social interactions and include scientific and technological contents. These contents are those who actually signed non-humans actors, as transgenic mammals, proteins, vectors for transduction, and so on, to provide some that Powell, Packalen and Whittington (2010) award only the organizations: "multiple means for information exchange, varied organizational strategies, and divergent criteria for success."

Although, ANT highlights the mechanism through which social and natural world takes shape (Callon, 1986), identifying how socio-technical associations were been made, it is much more on descriptive than explanatory foundational terms. (Law, 2008). Once innovation systems are characterized as aggregated of institutional forms and collective efforts within which science, technology, firms, education and political organizations have interactions (Edquist, 1997; Freeman, 1987), we suggest that future studies should emphasize a broader theoretical discussion between ANT and Institutional Theory as well as Evolutionary Theory to analyze dynamics of organizational field and innovation, especially when knowledge and learning must be explain as strategic factors, as proposes Lundvall (2005). 


\section{References}

CALLON, M. (1986). Some elements of sociology of translation: the domestication of the scallops and the fishermen of St. Brieux Bay. In: LAW, J. (ed.) Power, action and belief. Routledge \& Kegan. London, Pp. 196-229.

CALLON, M. (1989) Society in the making: the study of technology as a tool for sociological analysis. In: Pinch, T.; Hugues, T. Bijker, W. (eds.) The social construction of technological systems. MIT Press, Cambridge, MA.

CALLON, M.; Law, J.; Rip, A. (1986). A qualitative scientometrics. In: Callon, M.; Law, J.; Rip, A. (eds.) Mapping the dynamics of science and technology. Macmillan Press, London. Pp. 102-123.

CORIAT, B.; Orsi, F.; Weinstein, O. (2003). Does biotech reflect a new science-based innovation regime? Industry and Innovation. 10 (3). Pp. 23I-253.

DiMAGGIO, P.; Powell, W.W. (199I). The iron cage revisited: institutional isomorphism and collective rationality in organizational field. In: Powell, W.W.;

DiMAGGIO, P. (eds.) The new institutionalism in organizational analysis. University of Chicago Press, Chicago. pp. 63-82.

DOMÈNECH, M.; Tirado, F. (1998). Claves para la lectura de textos simétrico. In: Domènech, M.; Tirado, F. (comps.) Sociología simétrica. Gedisa Editorial, Barcelona. pp. 13-50.

EDQUIST, C. (1997). Systems of innovation approaches: their emergence and characteristics. In: Edquist, C. (ed.) Systems of innovation: technologies, institutions and organizations. Pinter, London.

FERNANDES, C. (2010) Redes de informação tecnológica. Dissertação de Mestrado. Universidade Federal de Pernambuco, Recife.

FREEMAN, C. (1987). Technology policy and economic performance: lesson from Japan. London, Pinter.

HOLT, R.T. (2008). Actor-network theory. In: The Sage Dictionary of Qualitative Management Research. Sage Publications, Oxford, UK. Pp. 23-24.
JUDICE, V. M.M.; Baêta, A. M.C. (2005). Modelo empresarial, gestão de inovação e investimentos de venture capital em empresas de biotecnologia no Brasil. Revista de Administração Contemporânea. 9 (I), |7|-|9|.

LATOUR, B. (1994). Jamais fomos modernos. Editora 34, São Paulo.

LATOUR, B. (2000). Ciência em ação. Editora Unesp, São Paulo.

LATOUR, B. (200I). A esperança de Pandora. Editora EDUSC, São Paulo.

LATOUR, B. (2005). Reassembling the social: an introduction to actor-network theory.Oxford University Press, Oxford, UK.

LATOUR, B.; Woolgar, S. (1997). A vida em laboratório. Relume Dumará, Rio de Janeiro.

LAW, J. (1999). After Ant. In: Law, J.; Hassard, J. (eds.) Actor Network Theory and after. Blackwell, Oxford, UK. pp. I-I4.

LAW, J. (2008). Actor-Network Theory and material semiotics. In Turner, B.S. The New Blackwell Companion to Social Theory. 3rd ed. Blackwell, Oxford. 14I-I58.

LAW, J.; Hetherington, K. (2000). Materialities, spatialities, globalities. Lancaster University. <http://www.comp.lancs. ac.uk/sociology/soc029jl.html>. [Accessed may, 22, 2003]

LILLICRAP, D.; Thompson, A. R. (2008). Gene therapy for hemophilia. World Federation of Hemophilia, Montreal.

LUNDVALL, B. (2005). National innovation systems: analytical concept and development tool. Druid tenth Anniversary Summer Conference. Copenhagen.

MARQUES, R.; Gonçalves Neto, C. (2007). The brazilian system of innovation in biotechnology: a preliminary study. Journal of Technology Management and Innovation. 2 (I). 55-63. 
MEYER, J.W. (2008). Reflections on institutional theories of organizations. In: Greenwood, R.; Oliver, C.; Suddaby, R.; Sahlin, K. (eds.) The Sage Handbook of Organizational Institutionalism. Sage Publications, Thousand Oaks, CA. pp. 788-809.

NIOSI, J. (2003). Alliances are not enough explaining rapid growth in biotechnology firms. Research Policy. 32. 737-750.

ORSENIGO, L. (2006). Clusters and clustering in biotechnology: stylized facts, issues and theories. In: Braunerhjelm, P. and Feldman, M.P. (eds.) Cluster Genesis. Oxford University Press, Oxford, UK. pp. 195-218.

OWEN-SMITH, J.; Riccaboni, M.; Pammolli, F; Powell, W.W. (2002). A comparison of US and European universityindustry relations in the life sciences. Management Science. 48. 24-43.

OWEN-SMITH, J.; Powell, P. (2004). Knowledge networks in the Boston biotechnology community. Organization Science. I5 (I). 5-2I.

OWEN-SMITH, J.; Powell, P. (2008). Networks And Institutions. In: Greenwood, R.; Oliver, C.; Suddaby, R.; Sahlin, K. (eds.) The Sage Handbook of Organizational Institutionalism. Sage Publications, Thousand Oaks, CA. pp. 594-621.

PORTER, K.; Whittington, K.B.; Powell, W.W. (2005). The institutional embeddedness of high-tech regions: relational foundations of the Boston biotechnology community. In: Breschi, S.; Malerba, F. Clusters, networks, and innovation. Oxford University Press, Oxford, UK. pp. 26I-296.

POWELL, W.W. (1999) The social construction of an organizational field: the case of biotechnology. International Journal of Biotechnology. I (I). 42-66.

POWELL. W.W.; Koput, K.W.; Smith-Doerr, L.(1996). Interorganizational collaboration and the locus of innovation: networks of learning in biotechnology. Administrative Science Quarterly. 4I (I). II6-I45.

POWELL, W.W.; Koput, K.W.; Bowie, J.I.; SmithDoerr, L. (2002). The Spatial Clustering Of Science And Capital: Accounting For Biotech Firm-Venture Capital Relationships. Regional Studies. 36 (3). 29I-306.
POWELL, W.W.; Koput, K.W.; White, D.R.; OwenSmith, J. (2005). Network dynamics in a field evolution: the growth of interorganizational collaboration in life sciences. American Journal of Sociology. 4 I (I). II32-I205.

POWELL, W.W.; Colyvas, J.A (2008). Microfoundations of institutional theory. In: Greenwood, R.; Oliver, C.; Suddaby, R.; Sahlin, K. (eds.) The Sage Handbook of Organizational Institutionalism. Sage Publications, Thousand Oaks, CA. pp. 276-298.

POWELL, W.W.; Packalen, K.A.; Whittington, K.B. (2010). Organizational and institutional genesis: the emergence of high-tech clusters in lifescience. In:Padgett,J.;Powell,W.W.; (eds.) The emergence of organization and markets. Queen's School of Business Research Paper. Kingston, Canada.

RIP, A. (1986). Mobilising resources through texts. In: Callon, M.; Law, J.; Rip, A. (eds.) Mapping the dynamics of science and technology. London: Macmillan Press. pp. 84-99.

SCOTT, W.R. (1994). Institutions and organizations: toward a theoretical synthesis. In: Scott, W.R; Meyer, J. W. Institutional environments and organizations. Sage Publications, Thousand Oaks, CA. pp. 55-80.

SCOTT, W.R. (1995). Institutions and organizations. Sage Publications, Thousand Oaks, CA.

TRIGUEIRO, M.G.S. (2002). O clone de prometeu: a biotecnologia no Brasil. Editora UnB, Brasília.

WFH (2008). Contraction fractionation. World Federation of Hemophilia, Montreal.

WHITTINGTON, K.B.; Owen-Smith, J.; Powell, W.W. (2009) Networks, propinquity and innovation in knowledge-intensive industries. Administrative Science Quarterly. 54 (I). 90-II2. 
J. Technol. Manag. Innov. 20I I,Volume 6, Issue 3 